\title{
Assessing behavioral intention toward green hotels during COVID-19 pandemic: the moderating role of environmental concern
}

\author{
Rajiv Kumar Dwivedi, Manoj Pandey, Anil Vashisht, Devendra Kumar Pandey and \\ Dharmendra Kumar
}

\begin{abstract}
Purpose - The study aims to investigate the consumers' behavioral intention toward green hotels. The tendency of individuals to afford green hotels is further escalating with progressing coronavirus disease-2019 (COVID-19) pandemic recurring waves. The increased worry of consumers toward health, hygiene and the climate is acquiring momentum and transforming how consumers traditionally perceive green hotels.

Design/methodology/approach - The study has recommended an integrated framework incorporating various research fields as attitude-behavior-context theory, theory of planned behavior (TPB) and moderating influences to study the associations among the antecedents of consumers' behavioral intention toward green hotels. The study comprised the participation of 536 respondents residing in the Delhi and National Capital Region (NCR) of India. The data analysis strategy involved the use of structural equation modeling (SEM) analysis to test the proposed research framework.

Findings - The results and findings of the study indicated a significant influence of fear and uncertainty of the COVID-19 pandemic and environmental concern on green trust. The results also revealed the considerable impact of green trust on willingness to pay premium, attitude and subjective norms, which significantly influenced behavioral intention. The analysis also revealed the moderating influence of environmental concern in the relationship of green trust and behavioral intention.

Research limitations/implications - The study has recommended significant theoretical. The theorists may use this research framework to analyze better the transforming consumer behavior trends toward green hotels in the ongoing fearful and uncertain COVID-19 pandemic scenario.

Practical implications - The study has recommended significant managerial implications. The industry practitioners may also utilize the framework to sustain the hotel business and bring new strategic insights into practice to combat the impact of the pandemic and simultaneously win consumers' trust in green hotels.

Originality/value - Although the researchers have previously emphasized consumers' intention toward green practices embraced by hotels, the impact of the COVID-19 pandemic on the green hotel ind ustry gained noticeable attention from researchers. Furthermore, there is a scarcity of literature providing insights on the behavioral dynamism of hotel customers' trust, attitude and willingness to pay for green hotels during the repetitive waves of the COVID-19 pandemic. The study will support the existing literature gap by enlightening the associations among the various antecedents of green hotels' behavioral intention, COVID-19 and environmental concern.
\end{abstract}

Keywords Behavioral intention, Green hotels, Green trust, COVID-19, Pandemic, Moderation

Paper type Research paper

\section{Introduction}

The COVID-19 pandemic has severely affected all business sectors worldwide, and the hotel sector remained among the worst affected ones. Like the vast majority of the ventures
Rajiv Kumar Dwivedi, Manoj Pandey, Anil Vashisht and Devendra Kumar Pandey are all based at the Amity Business School, Amity University, Gwalior, India. Dharmendra Kumar is based at the Delhi College of Technology and Management, Palwal, India.

Received 9 May 2021

Revised 23 October 2021 Accepted 13 January 2022

(C) Rajiv Kumar Dwivedi, Manoj Pandey, Anil Vashisht, Devendra Kumar Pandey and Dharmendra Kumar. Published in Journal of Tourism Futures. Published by Emerald Publishing Limited. This article is published under the Creative Commons Attribution (CC BY 4.0) licence. Anyone may reproduce, distribute, translate and create derivative works of this article (for both commercial and non-commercial purposes), subject to full attribution to the original publication and authors. The full terms of this licence may be seen at http:// creativecommons.org/licences/ by/4.0/legalcode. 
experiencing pandemic impacts, hospitality is also going to confront significant transformations expectedly. Liew (2020) concluded a sharp, quick fall in the tourism sector's productivity during the outbreak of the uncertain COVID-19 pandemic. The benchmarks achieved by the hotel industry before the intrusion of the COVID-19 pandemic globally are probably going to be recuperated back till the 2023 post-pandemic scenario (Krishnan et al., 2020). As far as China's hotel industry is concerned, it was the first to have a face-off with the COVID-19 infection and projected to be the first to reflect the indications of stabilization. However, the Indian hotel industry comparatively appears to stay fragile till 2021 as well (Dogra, 2020). The transformation of industrial activities toward climate-friendly green strategic approaches likewise noticed a halt during the spread of COVID disease. The hotel sector also got engaged with confronting the acute downfall in business than underlining the adoption of green hotels albeit green hotels will remain the foundation for the long-term sustainability of the hotel business (Hanson, 2020). The researchers also suggested the arguments of Balaji et al. (2019) that eco-friendly measures and green practices of hotels may result in favorable customers' sentiments about hotels' efforts for environmental concerns. Also, the market practices, such as green innovations, should be emphasized as core capabilities needed to work on societal transformations (Sigala, 2016).

The researchers need to extend further accentuation on the impact of environmental concerns on hotel business (Han et al., 2009, 2010). The effects of coronavirus infection further added dynamism into how the hotels were customarily working on maintaining hygiene and cleanliness. The research on hotel industry customers also revealed that the customers are trending to slant toward green hotels due to enhanced environmental concerns and brand trust, which is consequently because of fear and uncertainty of COVID-19 (Jian et al., 2020). The researchers further urged that this has strengthened customers' increased sacrifices and willingness to stay at green hotels during their traveling schedules. Pekovic (2021) also contended that green pull motives are significantly associated with the overall satisfaction level of travelers.

Hotel customers were more disposed toward their core context of staying at hotels instead of thinking about environment supportive actions earlier (Chen and Chang, 2013). The fear and uncertainty of coronavirus have developed customers' favorable attitudes toward hotels' green practices (Gossling et al., 2020; Jian et al., 2020). The behavioral intention of customers toward green hotels (Chaudhary, 2018; Hu et al., 2019; Yadav et al., 2019) have been reinforced drastically after the breakdown of the COVID-19 pandemic (Altuntas and Gok, 2021; Jiang and Wen, 2020).

The present study proposed an integrated framework of diverse fields of research as ABC Theory (Guagnano et al., 1995), TPB (Ajzen, 1991) and moderating influences (Tandon et al., 2020) to explore the consumer perception toward green hotels during the effects of COVID-19 pandemic. The hospitality literature indicates the need for hospitality researchers to work in research clusters consisting of researchers with assorted disciplines. The researchers will thus control the barriers arising due to focused single discipline research hindering the administration of specific crucial issues of the hospitality industry that requires cross-functional research and further finding better insights for tackling such issues (Okumus et al., 2018). The present study aimed following main objectives to achieve through the proposed framework:

1. To study the association of consumers' green trust and behavioral intention toward green hotels;

2. To study the roles of TPB components in the association of green trust and behavioral intention toward green hotels;

3. To explore the role of consumers' willingness to pay and fear and uncertainty of COVID-19 in the association of green trust and behavioral intention toward green hotels and

4. To investigate the moderating influence of environmental concern in the relationship of green trust and behavioral intention toward green hotels. 


\section{Theoretical review}

The investigations of behavioral dispositions associated with environmental balance gained significant momentum in the past (Bamberg, 2003; Prakash and Pathak, 2017). The outbreak of the COVID-19 pandemic catalyzed the focused drive of customers toward environmentally supportive green practices, health and hygiene orientated courses, social distancing and fine dining at restaurants (Gossling et al., 2020). The experience of pandemics' uncertainties further raised the consumers' confidence level and interest in environmentally facilitating commodities and amenities (Ho et al., 2020). The industry needs a revival of strategies to rebuild customers' faith in the travel and hotel industries, as investigations have revealed that now the customers are found to be more worried while traveling and staying. The customers may show an uplifting attitude toward traveling and staying at venues reporting a few COVID-19 cases and even thinking to get vaccinated to achieve safe traveling and staying at hotels (Gursoy and Chi, 2020). Hotels are now emphasizing more on local customers during the COVID-19 pandemic than ever before when these hotels focus on foreigners as a source of profitability (Yacoub and ElHajjar, 2021).

The TPB provides the fundamentals of understanding consumers' buying behavior toward products and services. Researchers have widely adopted TPB to evaluate the behavioral intention of consumers toward green practices of the hotel industry (Han et al., 2010; Verma and Chandra, 2018; Wang et al., 2018; Yadav et al., 2019). Consumers' behavioral intention is the tendency of consumers to behave explicitly toward a product or a service (Yadav et al., 2019). TPB indicated that the consumers' attitudes and subjective norms constitute the vital cognitive impetuses of their behavioral intention. Aizen (1991) defined attitude as the common favorable pre-disposition of consumers toward a specific behavior and subjective norm as the expected recommendation an individual tends to experience from the proximal societal linkages such as companions and relatives on the inevitable decision-making process.

Further, the ABC theory proposed that consumers' behavioral intention also results from a blend of specific attitudinal and situational determinants. Thus, the present theory used green trust and willingness to pay premium as situational determinants in the proposed framework to study behavioral intention in connection with attitudinal factors proposed by TPB theory (Yadav et al., 2019). Green hotels inculcate amicable environmental practices to underpin ecologically defensive measures (Green Hotels Associations, 2021). Green trust is "a willingness to depend on a product, service, or brand based on the belief or expectation resulting from its credibility, benevolence, and ability about its environmental performance" (Chen, 2010, p. 309). Slevitch et al. (2013) suggested that hotels emphasized products and services that correspond to an eco-friendly mechanism for projecting their green image. However, Berezan et al. (2013) indicated that the consumers focus more on functionally sophisticated green processes for justifying a hotels' green image, such as conserving energy and water. While Choi et al. (2015, p. 90) indicated existing disparities among the green practices of hotels that accord consumers' trust, others have argued that the intensity of consumers' trust toward a green hotel impacts their buying behaviors (Chen and Chang, 2013). Willingness to pay premium alludes to the extent of consumers' resilience to pay extra for green hotels (Chaudhary, 2018).

The fear of the COVID-19 pandemic is the emotional state of an individual corresponding to which individual encounters psychological issues such as depression and anxiety due to the perceived negative consequences of possibly getting infected with the coronavirus. Also, the uncertainty of COVID-19 pandemic corresponds to that cognitive state of an individual, which causes mental quandary to that individual due to rising infected cases in the community, lack of clinical help, increased unemployment and mercurial future outcomes of the pandemic (Jian et al., 2020; Koster et al., 2021; Yadegaridehkordi et al., 2020). Bitan et al. (2020) argued that the fear of COVID-19 is related to stress, anxiety and depression. As far as the researchers discuss the environmental concern, it is the extent of the willingness of an individual to accept the significance of environmental protection and extend the possible contribution for the same (Chaudhary, 2018; Paul et al., 2016; Prakash and Pathak, 2017). 
Significant research indicates the uprising consumption trends toward green hotels. The previous research studies suggested that the green encounters of green hotel visitors significantly affect their ubiquitous hotel satisfaction (Yu et al., 2017). Apart from consumers' attitudinal factors, the importance of environmental concern also adds weightage to consumers' appetite toward green hotels. The breakdown of the COVID-19 pandemic has catalyzed the need further to investigate the ongoing strategic restructuring of the hospitality industry worldwide.

\section{Building research framework}

\section{Green trust, attitude, subjective norms and behavioral intention}

Wu and Chen (2005) examined the impact of trust on the technology acceptance model (TAM) while studying users' online tax adoption behavior. The researchers established that the users' trust arose as a significant antecedent of both the attitude and subjective norm, significantly influencing behavioral intention toward online tax usage. An empirical investigation on university students occupied with computer courses unveiled that their trust greatly influences their participative attitude. Their participative attitude, in turn, affects their participative intention (Fang et al., 2009). In a study evaluating the usage of eco-friendly packaged products in India, the consumers' attitude significantly impacts purchase intention (Prakash and Pathak, 2017). A recent research study on eco-friendly hotels recommended that these hotels may persuade travelers to opt for pro-sustainable substitutes by utilizing sensual communication through social media (Kapoor et al., 2021). The quantitative study conducted by Ciftci and Çizel (2020) revealed that attitude components significantly predicted the online trust of tourists toward online travel intermediaries. Also, an investigation assessing the green hotel usage behavior in India indicated a significant role of green trust in the adoption behavior of consumers toward green hotels. The previous research suggests that the travelers' green trust is related to their attitude and subjective norms, which are further associated with their behavioral intention toward green hotels (Yadav et al., 2019). The perceived knowledge of COVID-19 likewise essentially impacted the tourists' subjective norms and attitudes which significantly affected their behavioral intention (Han et al., 2020). In a study of the attitude, green trust and purchase intention in the ongoing COVID-19 breakout environmental scenario, the attitude influences green trust, affecting consumers' purchase intention (Latip et al., 2020).

The conceptual groundwork of the examined literature enlightened the researchers in this study to propose as follows:

H1. Green trust significantly influences the behavioral intentions toward green hotels.

H2. Green trust significantly affects the subjective norms toward green hotels.

H3. Green trust significantly affects the attitude toward green hotels.

H4. Subjective norms significantly influence the behavioral intentions toward green hotels.

H5. Attitude significantly influences the behavioral intentions toward green hotels.

\section{Green trust, willingness to pay premium and behavioral intention}

Past research studies showed that green trust significantly affects the customers' willingness to pay premium for green hotels (Balaji et al., 2019; Yadav et al., 2019). A considerable volume of research also indicated that the willingness to pay premium significantly influences customers' behavioral intention concerning green hotels (Agag, 2019; Balaji et al., 2019; Yadav et al., 2019). In findings of a study based on hotel guests' standpoint toward green practices employed by the hotel industry, the more the guests were worried about the environment, the more they were willing to pay premium for green drives of hotels (Kang et al., 2012). The hospitality literature also indicated a significantly higher inclination of customers of certified green restaurants toward sharing their perspectives on green practices in contrast with non-certified green restaurant customers 
(Park et al., 2018). The researchers have likewise advised that the customers' willingness to pay premium toward green hotels further elevated during the COVID-19 outbreak (Jian et al., 2020).

Accordingly, the researchers propose the accompanying hypotheses on the foundation of pointed disquisition as follows:

H6. Green trust significantly influences the willingness to pay premium toward green hotels.

H7. Willingness to pay premium significantly affects the behavioral intention toward green hotels.

\section{Green trust, fear and uncertainty of COVID-19 and behavioral intention}

Gupta et al. (2021) studied the behavioral intention of Indian tourists using the health belief model. They argued that the tourists who have low efficacy and possesses high vulnerability for COVID-19 exposure abstain from heading out to India during the rising cases of COVID-19. The quest on the consumption of individual protective medical equipment in China during the COVID-19 outbreak caused consumers to favor online buying intention of equipment (Addo et al., 2020).

Jian et al. (2020) assessed the association of fear and uncertainty of COVID-19, behavioral intention toward green hotels and trust in green hotels. The study results highlighted that the fear and uncertainty of COVID-19 increased the customers' trust toward green hotels, which, in turn, enhanced their intention to stay at green hotels.

Thus, the researchers propose as follows:

H8. Green trust significantly influences fear of COVID-19.

H9. Green trust significantly influences the uncertainty of COVID-19.

H10. Fear of COVID-19 significantly influences behavioral intention toward green hotels.

H11. Uncertainty of COVID-19 significantly influences behavioral intention toward green hotels.

\section{Environmental concern and antecedents of behavioral intention}

The customers who are more prone to environmental protection concerns have a more optimistic attitude, which further enhances behavioral intentions (Hoang et al., 2019). The researchers have suggested that the fear and uncertainty of COVID-19 and the environmental concern of hotel customers influences their brand trust, which, in turn, contributes significantly toward their willingness to pay premium and thus behavioral disposition toward green hotels (Jian et al., 2020). Also, brand attitude mediates the relationship of brand knowledge and the brand performance in the restaurants utilizing green practices (Liu et al., 2020) and among trust and intentions of travelers (Zainal et al., 2017).

The environmental concern moderates the association of attitude and behavioral intention in previous studies (Cachero-Martínez, 2020; Hoang et al., 2020). Attitude, willingness to pay and environmental concern impacted behavioral intention (Prakash and Pathak, 2017). A study investigating hotel managers in India revealed that the environmental concern and attitude significantly impact the emerging Indian green hotel practices implementation (Verma and Chandra, 2018). A survey study based on TPB theory proposed that the online social media followers' attitudes and subjective norms significantly influence their behavioral intention, which significantly impacts their behavior (Harb et al., 2019). An empirical study utilizing SEM analysis on 559 respondents in Taiwan revealed that the consumers' environmental concern affects a significant impact on their subjective norms and attitude, both of which also casts a significant influence on their intention to avail services of green hotels (Chen and Tung, 2014). Yadav et al. (2019) recommended that the absence of attitude, willingness to pay premium and subjective norms prompt the decreased inclination of travelers for having a positive behavioral intention for green hotels. 
Consequently, the existing literature supports the researchers in proposing the accompanying hypotheses as follows:

H12. Environmental concern moderates the relationship between green trust and behavioral intention in a manner that the relationship is more potent when environmental concern is higher.

Figure 1 represents the conceptual framework proposed in this study.

\section{Methodology \\ Collection of data}

The data included 536 respondents of Delhi and the NCR of India. The researchers kept the criteria of respondents in the sample population as respondents having travel and stay experience to any outstation destination in the last year. The respondents reply through emails and social media platforms such as Linkedln by utilizing a survey questionnaire developed on the Google Form platform. The data collection from study participants was more appropriate using Internet tools since the ongoing COVID-19 epidemic has made contactless life and social distancing a need of the time. The participants offer a week to respond to the survey questionnaire at their convenience. The researchers gave the survey questionnaire to 1,000 people, out of whom 536 responded, revealing a response rate of $53.6 \%$, showing the appropriateness of the rate of submitted responses (Johnson and Owens, 2003) for a survey type investigation. There were no missing responses since data gathering involved the "required" option of the Google Form settings,

\section{Figure 1 The suggested framework}

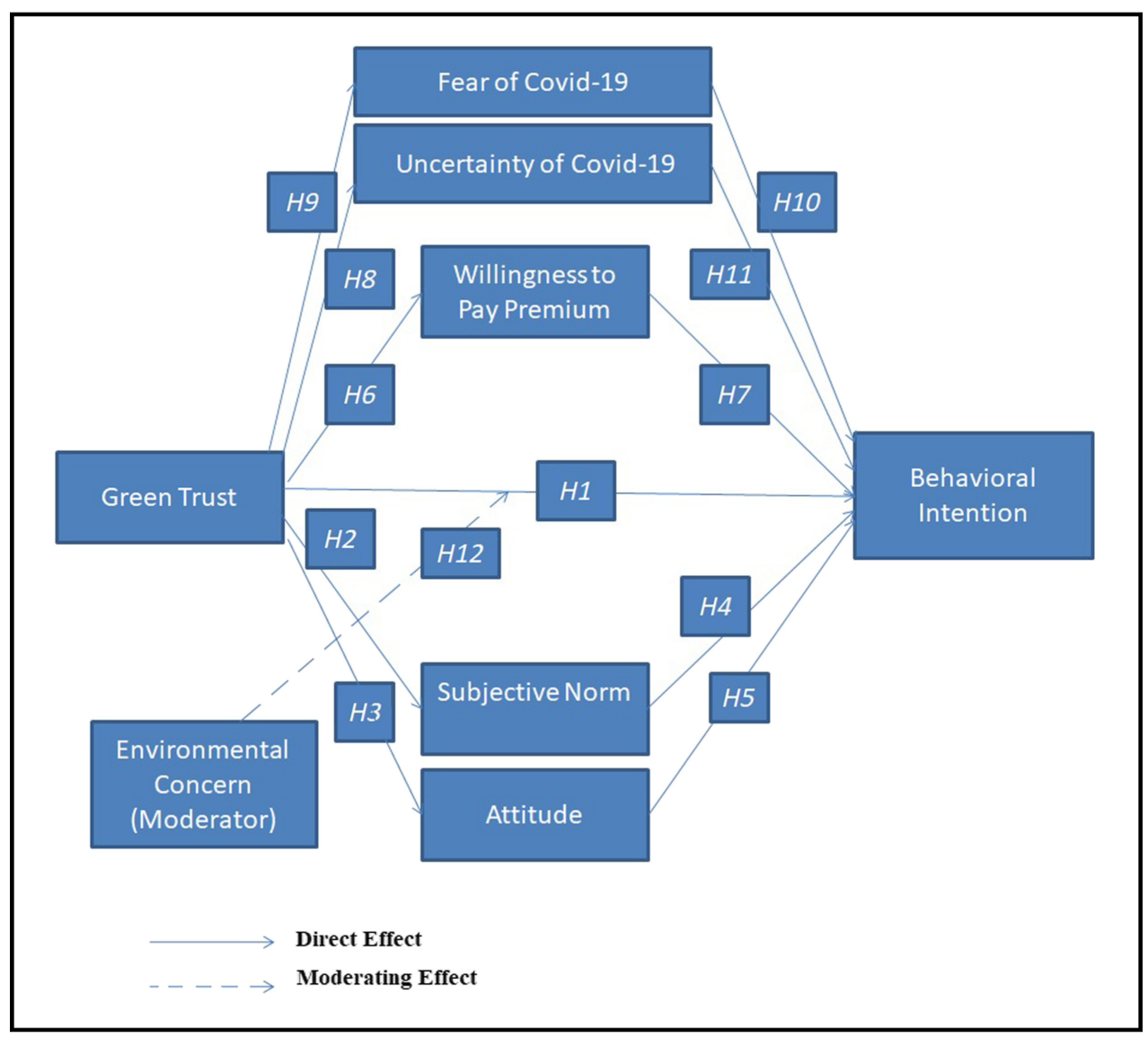

PAGE 6 | JOURNAL OF TOURISM FUTURES $\mid$ VOL. $\mathbf{m}$ NO. $\mathbf{m}$ 
ensuring that respondents respond to all fields before submitting the answered Google Form. The researchers also used Harman's single factor test (Harman, 1976) to evaluate common method bias (Podsakoff et al., 2003) and found that the responses were free of common method bias.

The following Table 1 represents the demographic profile of the participants of this investigation;

\section{Survey instruments}

The standard instruments included in this study are constructs adopted in previous research work in various organizational settings. The researchers had the four-item scale with items acquired from Kilbourne and Pickett (2008) to measure environmental concern. The four-item scale proposed by Bitan et al. (2020) to collect data for fear of COVID-19 and the three-item scale suggested by Andrews (2008) to collect responses for the uncertainty of COVID-19. The three-item scale for each of the subjective norms and the behavioral intention for green hotels and five-item scale for attitude with items acquired from Chen and Tung (2014) and Han et al. (2010) to gather responses for these constructs. The four items from Choi et al. (2015) were used to collect responses for green trust. Also, a three-item scale from Rahman and Reynolds (2016) was used to measure willingness to pay premium.

\section{Data analysis strategy}

The researchers included confirmatory factor analysis (CFA) to assess the measurement model and (SEM analysis to examine the proposed hypotheses in this study. The researchers perform data analysis using Statistical Package for the Social Sciences (SPSS) 25.0 and Analysis of Moment Structures (AMOS) 25.0 software in this study.

\section{Results and observations}

The authors assess the reliability of the constructs used in this study from Cronbach's alpha (Cronbach, 1951) and composite reliability (Fornell and Larcker, 1981). The results (Table 2) revealed that the measures of reliabilities for all the constructs are more than the recommended threshold value of 0.70 . Consequently, the scales utilized in this study emerge as adequately reliable. The researchers do not consider the third item of the environmental concern construct having low-factor loading from the data analysis exercise to avoid the impact of a less significant response scale on the comprehensive study. Further, average variance extracted (AVE) was used

\section{Table 1 Demographic profile of the respondents}

\begin{tabular}{llrr} 
Attribute & Categorical level & Number of respondents & Proportion \\
\hline Gender & Male & 322.00 & 60.07 \\
& Female & 214.00 & 39.92 \\
Age (years) & $0-30$ & 107.00 & 19.96 \\
& $30-45$ & 322.00 & 60.07 \\
& $45-60$ & 75.00 & 13.99 \\
Education & $60+$ & 32.00 & 5.97 \\
& Graduate & 43.00 & 8.02 \\
& PG & 364.00 & 67.91 \\
Experience (years) & Doctorate & 118.00 & 22.01 \\
& Other & 11.00 & 2.05 \\
& $0-5$ & 182.00 & 33.95 \\
& $6-10$ & 172.00 & 32.08 \\
& $11-15$ & 96.00 & 17.91 \\
Note(s): $N=536$ & $16-20$ yrs & 54.00 & 10.07 \\
& $21-25$ yrs & 32.00 & 5.97
\end{tabular}


Table 2 Correlations, reliability, average variance extracted (AVE) and descriptive statistics

\begin{tabular}{|c|c|c|c|c|c|c|c|c|c|c|c|c|c|c|}
\hline S. no. & Study variables & $x^{\prime}$ & $\mu$ & 1 & 2 & 3 & 4 & 5 & 6 & 7 & 8 & 9 & 10 & 11 \\
\hline 1 & Gender & 1.40 & 0.49 & & & & & & & & & & & \\
\hline 2 & Age & 1.71 & 0.85 & $0.35^{*}$ & & & & & & & & & & \\
\hline 3 & Education & 2.18 & 0.59 & $0.39^{* *}$ & $0.35^{*}$ & & & & & & & & & \\
\hline 4 & Green trust & 2.18 & 0.93 & 0.07 & 0.13 & 0.18 & 0.54 & & & & & & & \\
\hline 5 & Willingness to pay premium & 3.15 & 0.89 & 0.19 & 0.01 & 0.12 & $0.61^{* *}$ & 0.56 & & & & & & \\
\hline 6 & Subjective norm & 2.84 & 0.82 & 0.22 & 0.12 & 0.09 & $0.43^{\star \star}$ & $0.39^{\star \star}$ & 0.52 & & & & & \\
\hline 7 & Attitude & 3.65 & 0.84 & 0.12 & 0.04 & 0.01 & $0.46^{\star \star}$ & $0.26^{*}$ & $0.24^{*}$ & 0.54 & & & & \\
\hline 8 & Fear of COVID-19 & 3.19 & 0.87 & 0.15 & 0.02 & 0.06 & $0.11^{*}$ & $0.05^{\star}$ & $0.14^{*}$ & $0.19^{*}$ & 0.54 & & & \\
\hline 9 & Uncertainty of COVID-19 & 3.62 & 0.92 & 0.06 & 0.05 & 0.01 & $0.06^{\star}$ & $0.01^{\star}$ & $0.13^{*}$ & $0.08^{*}$ & $0.58^{\star *}$ & 0.53 & & \\
\hline 10 & Environmental concern & 2.83 & 0.67 & 0.12 & 0.06 & 0.18 & $0.04^{*}$ & $0.10^{*}$ & 0.02 & $0.23^{*}$ & $0.35^{*}$ & $0.26^{*}$ & 0.54 & \\
\hline 11 & Behavioral intention & 3.51 & 0.89 & 0.07 & 0.04 & 0.12 & $0.44^{* *}$ & $0.21^{*}$ & $0.31^{*}$ & $0.50^{\star}$ & $0.04^{*}$ & $0.24^{*}$ & $0.25^{*}$ & 0.56 \\
\hline
\end{tabular}

Note(s): ${ }^{* *} p<01,{ }^{*} p<05$, Average variance extracted (AVE) are mentioned across parentheses diagonally, $X$ : mean and $\mu$ : standard deviation

to assess the validity of the scales. The AVE values of all the constructs emerge out as more than 0.50 (Table 2), and in this manner, the scales utilized in the study possessed adequate validity. The noteworthy observations about reliability, validity, correlations and descriptive statistics are present in Table 2.

The factor loadings of all the items of the constructs used in this study remain significant as reported in Table 3, which also justifies the adequate validity of the proposed constructs.

The proposed model was found to be having good fit with the responses as found during CFA. Eight-factor solution was found from the measurement model of this study as $X^{2}(188)=360.001$, $\mathrm{CFI}=0.97, \mathrm{TLI}=0.83, \mathrm{IFI}=0.97, \mathrm{NFI}=0.95, \mathrm{RMSEA}=0.04, \mathrm{SRMR}=0.04$ and PClose $=0.000$. Comparative fit index (CFI), Tucker-Lewis index (TLI), Incremental fit index (IFI), Normed Fit Index (NFI), Root mean square error of approximation (RMSEA), Standardized root mean square residual (SRMR) were used to evaluate the model fit in this study. Also, the SEM analysis results revealed the good fit between the model and the data, as: $X^{2}(196)=398.001$, $\mathrm{CFI}=0.96, \mathrm{TLI}=0.81, \mathrm{IFI}=0.97, \mathrm{RMSEA}=0.04$ and $\mathrm{SRMR}=0.04$.

\section{Evaluation and testing of the research framework}

The researchers assess the hypotheses proposed in this study using effects and the significance of these effects between the constructs obtained from the SEM analysis. Table 4 contains all the results of the analysis. Hypothesis 1 found support as the green trust of the consumers was observed to impact their behavioral intention significantly $(E=0.44$ and $p<0.01)$. Also, Hypotheses 2, 3 and 6 were supported as consumers' green trust was found to impact their subjective norm ( $E=0.43$ and $p<0.01$ ), attitude $(E=0.45$ and $p<0.01)$ and willingness to pay premium $(E=0.61$ and $p<0.01$ ). The Hypotheses 4,5 and 7 were also supported as subjective norm $(E=0.31$ and $p<0.05)$, attitude $(E=0.50$ and $p<0.01)$ and willingness to pay premium $(E=0.21$ and $p<0.05)$ were observed to impact behavioral intention toward green hotels significantly.

Hypotheses 8, 9, 10 and 11 found support from the findings obtained from SEM analysis as the green trust found to be significantly influencing fear $(E=0.16$ and $p<0.05)$ and uncertainty $(E=0.26$ and $p<0.01)$ of COVID-19. Also, fear $(E=0.12$ and $p<0.05)$ and uncertainty $(E=0.19$ and $p<0.05$ ) of COVID-19 further found to be significantly influencing the behavioral intention toward green hotels.

The researchers examine the moderating influence of environmental concern in the relationship of green trust and behavioral intention toward green hotels using the three criteria suggested by Baron and Kenny (1986). At first, the moderator environmental concern does not relate directly to the dependent variable behavioral intention. Second, the interaction (Green Trust $\times$ Environmental 
Table 3 Indicators of reliability and validity of study constructs

\begin{tabular}{|c|c|c|c|c|}
\hline Study construct & Construct item & $\begin{array}{l}\text { Factor } \\
\text { loading }\end{array}$ & $\begin{array}{l}\text { Cronbach's } \\
\text { alpha }\end{array}$ & $\begin{array}{l}\text { Composite } \\
\text { reliability }\end{array}$ \\
\hline \multirow[t]{4}{*}{ Green trust } & $\begin{array}{l}\text { I feel that green hotels' environmental } \\
\text { commitments are generally reliable }\end{array}$ & 0.80 & 0.84 & 0.85 \\
\hline & $\begin{array}{l}\text { I feel that green hotels' environmental } \\
\text { performances are generally } \\
\text { dependable }\end{array}$ & 0.83 & & \\
\hline & $\begin{array}{l}\text { I feel that green hotels environmental } \\
\text { arguments are trustworthy }\end{array}$ & 0.82 & & \\
\hline & $\begin{array}{l}\text { I feel that green hotels keep the } \\
\text { environmental promises and } \\
\text { commitment they make }\end{array}$ & 0.75 & & \\
\hline \multirow[t]{3}{*}{$\begin{array}{l}\text { Willingness to pay } \\
\text { premium }\end{array}$} & $\begin{array}{l}\text { It is not acceptable for me to pay more } \\
\text { for a green hotel }\end{array}$ & 0.82 & 0.80 & 0.75 \\
\hline & I am willing to pay more for a green hotel & 0.81 & & \\
\hline & $\begin{array}{l}\text { I am willing to spend an extra amount of } \\
\text { money in order to stay at a green hotel }\end{array}$ & 0.70 & & \\
\hline \multirow[t]{3}{*}{ Subjective norm } & $\begin{array}{l}\text { People important to me, think that } \\
\text { I should stay at a green hotel }\end{array}$ & 0.74 & 0.89 & 0.81 \\
\hline & $\begin{array}{l}\text { Most people who are important to me } \\
\text { would want me to choose green hotels } \\
\text { while traveling }\end{array}$ & 0.81 & & \\
\hline & $\begin{array}{l}\text { People whose opinion I value would } \\
\text { want me to stay at green hotels }\end{array}$ & 0.82 & & \\
\hline \multirow[t]{6}{*}{ Attitude } & $\begin{array}{l}\text { For me staying at a green hotel while } \\
\text { traveling is (differential scale) }\end{array}$ & - & 0.86 & 0.84 \\
\hline & Extremely bad/extremely good & 0.80 & & \\
\hline & $\begin{array}{l}\text { Extremely undesirable/extremely } \\
\text { desirable }\end{array}$ & 0.83 & & \\
\hline & $\begin{array}{l}\text { Extremely unpleasant/extremely } \\
\text { pleasant }\end{array}$ & 0.82 & & \\
\hline & Extremely foolish/extremely wise & 0.80 & & \\
\hline & $\begin{array}{l}\text { Extremely unfavorable/extremely } \\
\text { favorable }\end{array}$ & 0.79 & & \\
\hline \multirow[t]{4}{*}{ Fear of COVID-19 } & I am afraid of the coronavirus & 0.83 & 0.88 & 0.74 \\
\hline & $\begin{array}{l}\text { It makes me uncomfortable to think } \\
\text { about the coronavirus }\end{array}$ & 0.82 & & \\
\hline & $\begin{array}{l}\text { I am afraid of losing my life because of } \\
\text { the coronavirus }\end{array}$ & 0.84 & & \\
\hline & $\begin{array}{l}\text { When watching news and stories about } \\
\text { the coronavirus on social media, } \\
\text { I become nervous or anxious }\end{array}$ & 0.87 & & \\
\hline \multirow[t]{3}{*}{$\begin{array}{l}\text { Uncertainty of } \\
\text { COVID-19 }\end{array}$} & $\begin{array}{l}\text { I perceive the context of COVID-19 as } \\
\text { very complex }\end{array}$ & 0.90 & 0.74 & 0.86 \\
\hline & $\begin{array}{l}\text { I perceive the context of COVID- } 19 \text { as } \\
\text { unpredictable }\end{array}$ & 0.88 & & \\
\hline & $\begin{array}{l}\text { Ul perceive the context of COVID-19 as } \\
\text { changing rapidly }\end{array}$ & 0.84 & & \\
\hline \multirow[t]{4}{*}{$\begin{array}{l}\text { Environmental } \\
\text { concern }\end{array}$} & $\begin{array}{l}\text { I am very concerned about the } \\
\text { environment }\end{array}$ & 0.80 & 0.79 & 0.82 \\
\hline & $\begin{array}{l}\text { I would be willing to reduce my } \\
\text { consumption to help protect the } \\
\text { environment }\end{array}$ & 0.78 & & \\
\hline & $\begin{array}{l}\text { Major social changes are necessary to } \\
\text { protect the natural environment }\end{array}$ & 0.83 & & \\
\hline & $\begin{array}{l}\text { Anti-pollution laws should be enforced } \\
\text { more strongly }\end{array}$ & 0.88 & & \\
\hline
\end{tabular}

continued) 
Table 3 Continued

\begin{tabular}{lllcc} 
Study construct & Construct item & $\begin{array}{c}\text { Factor } \\
\text { loading }\end{array}$ & $\begin{array}{c}\text { Cronbach's } \\
\text { alpha }\end{array}$ & $\begin{array}{c}\text { Composite } \\
\text { reliability }\end{array}$ \\
\hline $\begin{array}{l}\text { Behavioral } \\
\text { intention }\end{array}$ & $\begin{array}{l}\text { I am willing to stay at a green hotel while } \\
\text { travelling } \\
\text { I will make an effort to stay at a green } \\
\text { hotel when traveling } \\
\text { I plan to stay at a green hotel for my next } \\
\text { vacation }\end{array}$ & 0.76 & 0.74 & 0.78 \\
& 0.87 & & \\
Note(s): * Reverse scored item & &
\end{tabular}

Table 4 Structural equation modeling (SEM) analysis for testing proposed framework

Constructs and direction of effect

Direct effects (standardized)

\begin{tabular}{|c|c|c|}
\hline Green trust & $\rightarrow$ behavioral intention & $0.44^{* *}$ \\
\hline Green trust & $\rightarrow$ subjective norm & $0.43^{\star *}$ \\
\hline Green trust & $\rightarrow$ attitude & $0.45^{\star *}$ \\
\hline Green trust & $\rightarrow$ willingness to pay premium & $0.61^{* *}$ \\
\hline Green trust & $\rightarrow$ fear of COVID-19 & $0.16^{*}$ \\
\hline Green trust & $\rightarrow$ uncertainty of COVID-19 & $0.26^{* *}$ \\
\hline \multicolumn{2}{|c|}{ Fear of COVID-19 $\rightarrow$ behavioral intention } & $0.12^{*}$ \\
\hline \multicolumn{2}{|c|}{ Uncertainty of COVID-19 $\rightarrow$ behavioral intention } & $0.19^{*}$ \\
\hline \multicolumn{2}{|c|}{ Willingness to pay premium $\rightarrow$ behavioral intention } & $0.21^{*}$ \\
\hline \multicolumn{2}{|c|}{ Subjective norm $\rightarrow$ behavioral intention } & $0.31^{*}$ \\
\hline \multicolumn{2}{|c|}{ Attitude $\rightarrow$ behavioral intention } & $0.50^{\star *}$ \\
\hline \multicolumn{3}{|c|}{ Note(s): ${ }^{* *} p<0.01 ;{ }^{*} p<0.05$ and $N=536$} \\
\hline
\end{tabular}

Concern) was significant, and third, the moderator environmental concern functions as an independent variable. Thus, all the three criteria recommended were satisfied. Also, researchers evaluate the moderating influence using the moderated SEM (MSEM) approach suggested by Ping Jr (1995) to test the moderating influence. The results of the analysis show a good model fit with the data, as $X^{2}[120]=170.980, \mathrm{CFI}=0.96, \mathrm{IFI}=0.98, \mathrm{RMSEA}=0.02$ and $\mathrm{SRMR}=0.04$. Also, the interaction coefficient was found to be significant $(B=0.064$ and $p<0.01)$. The results thus show that the relationship between green trust and behavioral intention is stronger when environmental concern is higher. Conclusively, Hypothesis 12 is supported.

Figure 2 represents the moderating impact of environmental concern in the relationship between green trust and behavioral intention toward green hotels. The figure indicates that environmental concern strengthens the positive relationship between green trust and behavioral intention.

The conceptual framework proposed in this study was subsequently verified hypothetically and empirically and addressed in Figure 3.

\section{Discussion}

The popularity of green practices adopted by the hotel industry is expanding considerably with time. Additionally, the consumers with a tendency toward environmental protection concerns possess increased favorableness toward green hotels after the spread of the COVID-19 infection. This study has proposed a novel framework for future research enthusiasts to examine consumers' behavioral intention toward green hotels. There is a colossal deficit of accessible literature with an exploratory emphasis on moderating influences of environmental concern (Cachero-Martínez, 2020).

This study empirically validates the association between consumers' green trust and their behavioral intention. The study found support from previous literature, such as Rai and Nayak 


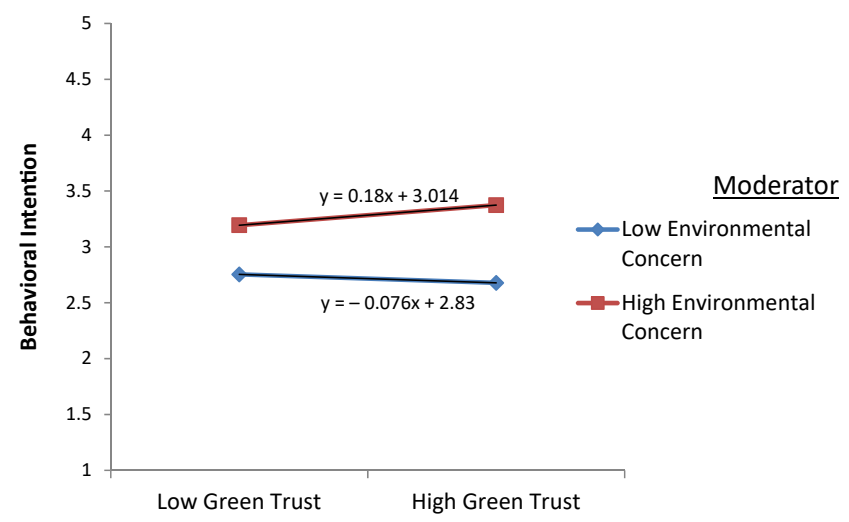

\section{Figure 3 The empirically tested framework}

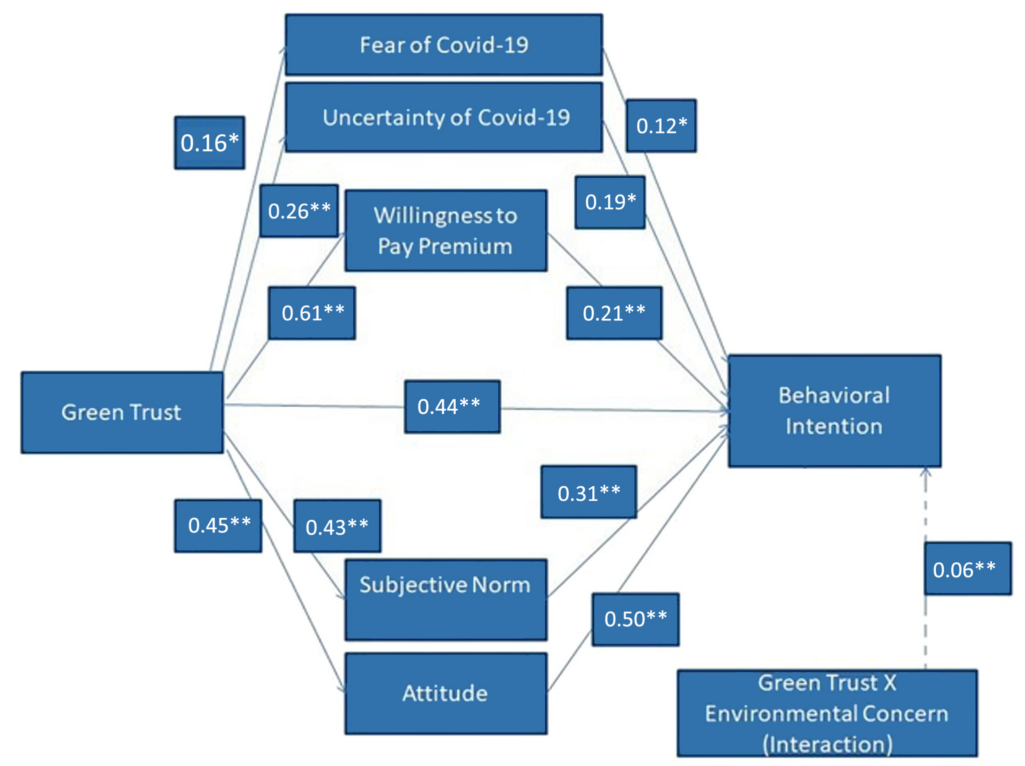

Direct Effect

Moderating Effect

(2019, p. 29) found that brand trust is the vital determinant in the building of emotional commitment of customers toward a hospitality brand. The study also indicated significant influences of fear and uncertainty of the COVID-19 pandemic on consumers' green behavioral intention (Altuntas and Gok, 2021; Jian et al., 2020; Jiang and Wen, 2020). The study also upheld the existing literature on the significant impacts of green trust and willingness to pay premium, attitude and subjective norms. The study also indicates the significant effect of these antecedents on consumers' behavioral intentions toward green hotels. The study also adds the innovative finding of moderating effect of environmental concern in the association of green trust and behavioral intention to the existing literature. This study shows that the consumers' green trust casts an increasingly significant influence on behavioral intention toward green hotels when consumers have more 
significant environmental concerns than the lower ones. These results further extend support to the findings of the past examinations (Balaji et al., 2019; Han et al., 2020; Jian et al., 2020; Verma and Chandra, 2018; Wang et al., 2018; Yadav et al., 2019).

Subsequently, this study enriches the accessible hospitality literature by featuring different vital determinants of consumers' behavioral intention and the moderating impact of environmental concern in the proposed framework during the surging wave of the ferocious COVID-19 pandemic.

\section{Theoretical implications}

This study has proposed valuable theoretical contributions in the area of the hotel industry. This study has suggested an extended theoretically and empirically validated framework of antecedents of consumers' behavioral intentions toward green hotels in India. This proposed framework is a unique integrated framework of diverse research theories, such as TPB theory, ABC theory and moderating influences. The framework has well supported the past research works (Cachero-Martínez, 2020; Chaudhary, 2018; Chen and Chang, 2013; Han et al., 2010, 2020; Yadav et al., 2019).

Further, it is evident from the review of hospitality literature that many studies explored the antecedents of the behavioral intention of consumers toward hotels. Yet, the available research on the association of the behavioral intention of travelers and the green practices adopted by hotels during environmental vulnerabilities such as COVID-19 are not many. Accordingly, this study fills this gap of current literature too.

Additionally, this study contributed critical highlights on the roles of fear and uncertainty of COVID-19 pandemic on the proposed framework of behavioral intention of consumers toward green hotels. The results also support those research studies associated with environmentally supportive activities by integrating environmental concerns in the proposed framework. Postma and Yeoman (2021, p. 74) recommended the future tourism sector acquire strategic foresight and scenario planning competence to generate adaptive capacity to achieve advantage from natural contingencies through resilience rather than making efforts to avoid their damaging effects. Thus, the study results are vital for researchers exploring future tourism strategies and policies that can build resilience toward vulnerabilities such as the COVID-19 pandemic.

Finally, the study is a significant endeavor to bring researchers' attention to the strategic restructuring of the hospitality industry, which is one of the most barely hit industries during repeating COVID-19 pandemic waves (Craven et al., 2021).

\section{Managerial implications}

This study indicates some exceptionally valuable implications for hotel industry managers. This study suggests that subjective norms and attitude impacts travelers behavioral intentions positively. Subsequently, the hotel managers need to alter their traditional health and cleanliness practices so that consumers may perceive them as adequate as per the continuous pandemic situation, such as implementing and featuring contactless and mobile app-based services. Second, communication is an important ingredient in accomplishing sustainability and building green capacities (McCartney and Leong, 2018). Thus, the hotel managers must maintain effective communication with employees concerning their enhancements in green strategies. Jamal and Budke (2020) suggested that viable communication of precise insights about the diseases such as coronavirus will support travelers from various dilemmas and the disclosure of scientific data and recommended precautions will make a concrete approach of practitioners toward future tourism at both domestic and global level. A study conducted by McKinsey on 5,000 employees during the second wave of COVID-19 revealed that effective communication with employees will improve their productivity at work (Craven et al., 2021).

PAGE 12 |JOURNAL OF TOURISM FUTURES $\mid$ VOL. $\mathbf{m}$ NO. $\mathbf{m}$ 
Consequently, this recommendation will make employees more confident and productive. The second wave of the COVID-19 pandemic has indicated the role of COVID-19 that is probably going to make mindfulness regarding health issues among the consumers each time there is the redundant influx of COVID-19 or such infectious diseases in future. A health belief model-based study revealed that tourists tend to avoid traveling to India during the COVID-19 spread due to vulnerability of exposure to coronavirus infection (Gupta et al., 2021). Thus, the study recommends hotel managers implement green practices such as online booking, contactless payments, dining with social distancing and providing local customers with a chance to stay and enjoy a safe and recreational environment to invigorate their minds in a time of the pandemic. Such practices will enhance travelers' trust toward green hotels and improve their tendency toward environmental concerns, further resulting in their increased attitudinal pre-dispositional behavioral intention toward green hotels.

Simultaneously, the study results on willingness to pay premium and subjective norms help the researchers recommend hotel managers increase positive communication regarding hotels' green practices through social media. As, during the pandemic time, the population is highly interested in knowing the trends in social media, it could be an opportunity for hotels' marketing managers to add the significance of green hotel practices in the behavioral buying criteria of hotel consumers.

\section{Limitations of the study and directions for future research}

Although this study extends recommendations and results of high worth for theoretical and managerial purposes, the study still has some limitations that future researchers can emphasize.

At first, the study is survey-based and doesn't add anything experimentally, whereas the experimental research on green hotels may add more critical values in terms of results and findings. Such as investigating how a green practice supported with an artificial intelligence-based application in a controlled hotel setting influences the green trust and behavior of hotel visitors can be a valuable experimental study. Second, this study is a one-time study conducted during the second wave of the COVID-19 pandemic. Although a longitudinal study to detect consumers' behavioral intention toward green hotels during recurring waves of the pandemic will give more reliable findings.

Further, this study indicated some antecedents of the behavioral intention of travelers during COVID-19. Still, an expanded focus on assessing different factors that may impact the future of travel and tourism is of prime importance for future research. As, while connecting the present, past and future of tourism amid the COVID-19 pandemic, Higgins-Desbiolles et al. (2021, p. 9) concluded that "[ . . . COVID-19's interruption invites us to look to tourism's past to help us in our imaginings to enable a better future." Illustratively, Matiza (2020) suggested future tourism industry practitioners explore the association of perceived risk and the COVID-19 pandemic to predict the post-pandemic behavior of travelers.

Dolnicar et al. (2015) expressed concern over researchers' emphasis on behavioral intention to comprehend the satisfaction-behavioral intention linkage. Since such a link provides supportive machinery for tourism industry leaders to augment their market strategies, future tourism industry researchers need to validate behavioral intentions' role in travelers' response to the tourism industry. The researchers further contended that the contribution of behavioral intentions of tourists toward destinations is rather complex than as understood by the researchers and need investigation of other determinants that are responsible for tourists' actual behavior. The researcher also indicated the required emphasis of researchers on optimum usage of constructs to measure behavioral intention to avoid common method bias, which can prompt vagueness in findings and results of the studies. Accordingly, this study has empirically investigated the behavioral intentions of travelers during the COVID-19 pandemic. Future researchers should stress assessing actual behavior rather than behavioral intentions, which seems to be a complex proxy for actual behavior during environmental uncertainties and pandemics such as the COVID-19 pandemic.

Subsequently, future researchers may focus on many such aspects to further expand the horizon of green hotel research.

VOL. m. NO. m| $\mid$ JOURNAL OF TOURISM FUTURES $\mid$ PAGE 13 


\section{References}

Addo, P.C., Jiaming, F., Kulbo, N.B. and Liangqiang, L. (2020), "COVID-19: fear appeal favoring purchase behavior towards personal protective equipment", The Service Industries Journal, Taylor \& Francis, Vol. 40, Nos 7-8, pp. 471-490.

Agag, G. (2019), "Understanding the determinants of guests' behaviour to use green P2P accommodation", International Journal of Contemporary Hospitality Management, Emerald Publishing, Vol. 31 No. 9, pp. 3417-3446.

Ajzen, I. (1991), "The theory of planned behavior", Organizational Behavior and Human Decision Processes, Elsevier, Vol. 50 No. 2, pp. 179-211.

Altuntas, F. and Gok, M.S. (2021), "The effect of COVID-19 pandemic on domestic tourism: A DEMATEL method analysis on quarantine decisions", International Journal of Hospitality Management, Elsevier, Vol. 92, January, 102719.

Andrews, R. (2008), "Perceived environmental uncertainty in public organizations: an empirical exploration", Public Performance and Management Review, Taylor \& Francis, Vol. 32 No. 1, pp. 25-50.

Balaji, M.S., Jiang, Y. and Jha, S. (2019), "Green hotel adoption: a personal choice or social pressure?", International Journal of Contemporary Hospitality Management, Emerald Publishing, Vol. 31 No. 8, pp. 3287-3305.

Bamberg, S. (2003), "How does environmental concern influence specific environmentally related behaviors? A new answer to an old question", Journal of Environmental Psychology, Elsevier, Vol. 23 No. 1, pp. 21-32.

Baron, R.M. and Kenny, D.A. (1986), "The moderator-mediator variable distinction in social psychological research: conceptual, strategic, and statistical considerations”, Journal of Personality and Social Psychology, Vol. 51 No. 6, pp. 1173-1182.

Berezan, O., Raab, C., Yoo, M. and Love, C. (2013), "Sustainable hotel practices and nationality: the impact on guest satisfaction and guest intention to return", International Journal of Hospitality Management, Vol. 34, September, pp. 227-233, doi: 10.1016/j.jijhm.2013.03.010.

Bitan, D.T., Grossman-Giron, A., Bloch, Y., Mayer, Y., Shiffman, N. and Mendlovic, S. (2020), "Fear of COVID-19 scale: psychometric characteristics, reliability and validity in the Israeli population", Psychiatry Research, Elsevier, Vol. 289, July, 113100, doi: 10.1016/j.psychres.2020.113100.

Cachero-Martínez, S. (2020), "Consumer behaviour towards organic products: the moderating role of environmental concern", Journal of Risk and Financial Management, Multidisciplinary Digital Publishing Institute, Vol. 13 No. 12, p. 330.

Chaudhary, R. (2018), "Green buying behavior in India: an empirical analysis", Journal of Global Responsibility, Emerald Publishing, Vol. 9 No. 2, pp. 179-192.

Chen, Y.-S. (2010), "The drivers of green brand equity: green brand image, green satisfaction, and green trust", Journal of Business Ethics, Springer, Vol. 93 No. 2, pp. 307-319.

Chen, Y.-S. and Chang, C.-H. (2013), "Greenwash and green trust: the mediation effects of green consumer confusion and green perceived risk", Journal of Business Ethics, Springer, Vol. 114 No. 3, pp. 489-500.

Chen, M.-F. and Tung, P.-J. (2014), "Developing an extended theory of planned behavior model to predict consumers' intention to visit green hotels", International Journal of Hospitality Management, Elsevier, Vol. 36, January, pp. 221-230.

Choi, H., Jang, J. and Kandampully, J. (2015), "Application of the extended VBN theory to understand consumers' decisions about green hotels", International Journal of Hospitality Management, Elsevier, Vol. 51, October, pp. 87-95.

Ciftci, S.F. and Cizel, B. (2020), "Predictors of e-trust for Web-based travel intermediaries: a survey on Istanbul visitors", Journal of Hospitality and Tourism Technology, Emerald Publishing, Vol. 11 No. 4, pp. 667-680.

Craven, M., Liu, L., Wilson, M. and Mysore, M. (2021), "COVID-19: implications for business”, 28 April, available at: https:/www.mckinsey.com/business-functions/risk/our-insights/covid-19-implications-forbusiness (accessed 5 May 2021).

Cronbach, L.J. (1951), "Coefficient alpha and the internal structure of tests", Psychometrika, Vol. 16 No. 3 , pp. 297-334.

PAGE $14 \mid$ JOURNAL OF TOURISM FUTURES $\mid$ VOL. m. NO. 
Dogra, S. (2020), "COVID-19: impact on the hospitality workforce", EHL Insights, available at: https:// hospitalityinsights.ehl.edu/covid-19-impact-hospitality-workforce (accessed 25 December 2021).

Dolnicar, S., Coltman, T. and Sharma, R. (2015), "Do satisfied tourists really intend to come back? Three concerns with empirical studies of the link between satisfaction and behavioral intention", Journal of Travel Research, Sage Publications Sage CA, Los Angeles, CA, Vol. 54 No. 2, pp. 152-178.

Fang, J., Shao, P. and Lan, G. (2009), "Effects of innovativeness and trust on web survey participation", Computers in Human Behavior, Elsevier, Vol. 25 No. 1, pp. 144-152.

Fornell, C. and Larcker, D.F. (1981), "Structural equation models with unobservable variables and measurement error: algebra and statistics", Journal of Marketing Research, Vol. 18 No. 1, pp. 382-388.

Gossling, S., Scott, D. and Hall, C.M. (2020), "Pandemics, tourism and global change: a rapid assessment of COVID-19", Journal of Sustainable Tourism, Taylor \& Francis, Vol. 29 No. 1, pp. 1-20.

Green Hotels Associations (2021), "Why should hotels be green?", available at: http://greenhotels.com/ index.php (accessed 30 April 2021).

Guagnano, G.A., Stern, P.C. and Dietz, T. (1995), "Influences on attitude-behavior relationships: a natural experiment with curbside recycling", Environment and Behavior, Sage Publications Sage CA, Thousand Oaks, CA, Vol. 27 No. 5, pp. 699-718.

Gupta, V., Cahyanto, I., Sajnani, M. and Shah, C. (2021), "Changing dynamics and travel evading: a case of Indian tourists amidst the COVID 19 pandemic", Journal of Tourism Futures, Emerald Publishing, Vol. ahead of print No. ahead of print. doi: 10.1108/JTF-04-2020-0061.

Gursoy, D. and Chi, C.G. (2020), "Effects of COVID-19 pandemic on hospitality industry: review of the current situations and a research agenda", Journal of Hospitality Marketing and Management, Vol. 29 No. 5, pp. 527-529.

Han, H., Hsu, L.-T.J. and Lee, J.-S. (2009), "Empirical investigation of the roles of attitudes toward green behaviors, overall image, gender, and age in hotel customers' eco-friendly decision-making process", International Journal of Hospitality Management, Elsevier, Vol. 28 No. 4, pp. 519-528.

Han, H., Hsu, L.-T.J. and Sheu, C. (2010), "Application of the theory of planned behavior to green hotel choice: testing the effect of environmental friendly activities", Tourism Management, Elsevier, Vol. 31 No. 3, pp. 325-334.

Han, H., Al-Ansi, A., Chua, B.-L., Tariq, B., Radic, A. and Park, S. (2020), "The post-coronavirus world in the international tourism industry: application of the theory of planned behavior to safer destination choices in the case of US outbound tourism", International Journal of Environmental Research and Public Health, Multidisciplinary Digital Publishing Institute, Vol. 17 No. 18, p. 6485.

Hanson, E. (2020), "Keeping green: sustainability and Covid-19 - BHN", Boutique Hotel News, available at: https://www.boutiquehotelnews.com/features/keeping-green-sustainability-and-covid-19 (accessed 25 December 2021).

Harb, A.A., Fowler, D., Chang, H.J.J., Blum, S.C. and Alakaleek, W. (2019), "Social media as a marketing tool for events", Journal of Hospitality and Tourism Technology, Emerald Publishing, Vol. 10 No. 1, pp. 28-44.

Harman, H.H. (1976), Modern Factor Analysis, University of Chicago Press, Chicago, London.

Higgins-Desbiolles, F., Bigby, B.C. and Doering, A. (2021), "Socialising tourism after COVID-19: reclaiming tourism as a social force?", Journal of Tourism Futures, Emerald Publishing, Vol. ahead of print No. ahead of print. doi: 10.1108/JTF-03-2021-0058.

Ho, J., Hui, D., Kim, A. and Zhang, Y. (2020), "Chinese consumer behavior post-COVID-19", McKinsey, 31 March, available at: https:/www.mckinsey.com/industries/consumer-packaged-goods/our-insights/ cautiously-optimistic-chinese-consumer-behavior-post-covid-19 (accessed 30 April 2021).

Hoang, H.C., Miloslava, C., Hoang, T.Q.H. and Jibril, A.B. (2019), "The theory of planned behavior toward organic food in vietnam: the moderation of environmental concern", Presented at the 15th International Bata Conference for Ph.D. Students and Young Researchers, pp. 362-374.

Hoang, H.C., Chovancová, M. and Hoang, T.Q.H. (2020), "The interactive effect of level of education and environmental concern toward organic food in Vietnam", Journal of Distribution Science, Korea Distribution Science Association (KODISA), Vol. 18 No. 9, pp. 19-30.

Hu, J., Liu, Y.-L., Yuen, T.W.W., Lim, M.K. and Hu, J. (2019), "Do green practices really attract customers? The sharing economy from the sustainable supply chain management perspective", Resources, Conservation and Recycling, Elsevier, Vol. 149, October, pp. 177-187. 
Jamal, T. and Budke, C. (2020), "Tourism in a world with pandemics: local-global responsibility and action", Journal of Tourism Futures, Emerald Publishing, Vol. 6 No. 2, pp. 181-188.

Jian, Y., Yu, I.Y., Yang, M.X. and Zeng, K.J. (2020), "The impacts of fear and uncertainty of COVID-19 on environmental concerns, brand trust, and behavioral intentions toward green hotels", Sustainability, Multidisciplinary Digital Publishing Institute, Vol. 12 No. 20, p. 8688.

Jiang, Y. and Wen, J. (2020), "Effects of COVID-19 on hotel marketing and management: a perspective article", International Journal of Contemporary Hospitality Management, Emerald Publishing, Vol. 32 No. 8, pp. 2563-2573.

Johnson, T. and Owens, L. (2003), "Survey response rate reporting in the professional literature", 58th Annual Meeting of the American Association for Public Opinion Research, Vol. 2003, Nashville.

Kang, K.H., Stein, L., Heo, C.Y. and Lee, S. (2012), "Consumers' willingness to pay for green initiatives of the hotel industry", International Journal of Hospitality Management, Elsevier, Vol. 31 No. 2, pp. 564-572.

Kapoor, P.S., Balaji, M.S. and Jiang, Y. (2021), "Effectiveness of sustainability communication on social media: role of message appeal and message source", International Journal of Contemporary Hospitality Management, Emerald Publishing, Vol. 33 No. 3, pp. 949-972.

Kilbourne, W. and Pickett, G. (2008), "How materialism affects environmental beliefs, concern, and environmentally responsible behavior", Journal of Business Research, Elsevier, Vol. 61 No. 9, pp. 885-893.

Koster, E.S., Philbert, D. and Bouvy, M.L. (2021), "Impact of the COVID-19 epidemic on the provision of pharmaceutical care in community pharmacies", Research in Social and Administrative Pharmacy, Elsevier, Vol. 17 No. 1, pp. 2002-2004.

Krishnan, V., Mann, R., Seitzman, N. and Wittkamp, N. (2020), "Hospitality and COVID-19: how long until 'no vacancy' for US hotels?", McKisney \& Company - Travel, Logistics \& Infrastructure, 10 June, available at: https://www.mckinsey.com/industries/travel-logistics-and-infrastructure/our-insights/hospitality-and-covid19-how-long-until-no-vacancy-for-us-hotels\# (accessed 25 April 2021).

Latip, M.S.A., Newaz, F.T., Ramasamy, R., Tumin, S.A. and Noh, I. (2020), "How do food safety knowledge and trust affect individual's green considerations during the Covid-19 pandemic in Malaysia?", Malaysian Journal of Consumer and Family Economics, Vol. 24, October, pp. 261-285.

Liew, V.K.-S. (2020), "The effect of novel coronavirus pandemic on tourism share prices", Journal of Tourism Futures, Emerald Publishing, Vol. ahead of print No. ahead of print. doi: 10.1108/JTF-03-2020-0045.

Liu, K.-N., Hu, C., Lin, M.-C., Tsai, T.-I. and Xiao, Q. (2020), "Brand knowledge and non-financial brand performance in the green restaurants: mediating effect of brand attitude”, International Journal of Hospitality Management, Elsevier, Vol. 89, August, 102566.

Matiza, T. (2020), "Post-COVID-19 crisis travel behaviour: towards mitigating the effects of perceived risk", Journal of Tourism Futures, Emerald Publishing, Vol. ahead-of-print No. ahead-of-print. doi: 10.1108/JTF04-2020-0063.

McCartney, G. and Leong, V.M.W. (2018), "An examination of the impact of green impressions by delegates toward a trade show", Journal of Convention and Event Tourism, Taylor \& Francis, Vol. 19 No. 1, pp. 25-43, doi: 10.1080/15470148.2017.1367980.

Okumus, F., van Niekerk, M., Koseoglu, M.A. and Bilgihan, A. (2018), "Interdisciplinary research in tourism", Tourism Management, Elsevier, Vol. 69, December, pp. 540-549.

Park, E.O., Chae, B.K. and Kwon, J. (2018), "The structural topic model for online review analysis: comparison between green and non-green restaurants", Journal of Hospitality and Tourism Technology, Emerald Publishing, Vol. 11 No. 1, pp. 1-17.

Paul, J., Modi, A. and Patel, J. (2016), "Predicting green product consumption using theory of planned behavior and reasoned action", Journal of Retailing and Consumer Services, Elsevier, Vol. 29, March, pp. 123-134.

Pekovic, S. (2021), "Green pull motives and overall tourist satisfaction: a macro-and micro-levels analysis", International Journal of Contemporary Hospitality Management, Emerald Publishing, Vol. 33 No. 4, pp. 1368-1390.

Ping, R.A. Jr (1995), "A parsimonious estimating technique for interaction and quadratic latent variables", Journal of Marketing Research, SAGE Publications Sage CA, Los Angeles, CA, Vol. 32 No. 3, pp. 336-347.

Podsakoff, P.M., MacKenzie, S.B., Lee, J.-Y. and Podsakoff, N.P. (2003), "Common method biases in behavioral research: a critical review of the literature and recommended remedies", Journal of Applied Psychology, Vol. 88 No. 5, pp. 879-903.

PAGE $16 \mid$ JOURNAL OF TOURISM FUTURES $\mid$ VOL. $\mathbf{m}$ NO. $\mathbf{m}$ 
Postma, A. and Yeoman, I.S. (2021), "A systems perspective as a tool to understand disruption in travel and tourism", Journal of Tourism Futures, Emerald Publishing, Vol. 7 No. 1, pp. 67-77.

Prakash, G. and Pathak, P. (2017), "Intention to buy eco-friendly packaged products among young consumers of India: a study on developing nation", Journal of Cleaner Production, Elsevier, Vol. 141, January, pp. 385-393.

Rahman, I. and Reynolds, D. (2016), "Predicting green hotel behavioral intentions using a theory of environmental commitment and sacrifice for the environment", International Journal of Hospitality Management, Elsevier,Vol. 52, January, pp. 107-116.

Rai, S. and Nayak, J.K. (2019), "Hospitality branding in emerging economies: an Indian perspective", Journal of Tourism Futures, Emerald Publishing, Vol. 5 No. 1, pp. 22-34.

Sigala, M. (2016), "Learning with the market: a market approach and framework for developing social entrepreneurship in tourism and hospitality", International Journal of Contemporary Hospitality Management, Emerald Group Publishing, Vol. 28 No. 6, pp. 1245-1286.

Slevitch, L., Mathe, K., Karpova, E. and Scott-Halsell, S. (2013), “'Green' attributes and customer satisfaction: optimization of resource allocation and performance", International Journal of Contemporary Hospitality Management, Vol. 25 No. 6, pp. 802-822, doi: 10.1108/IJCHM-07-2012-0111.

Tandon, A., Dhir, A., Kaur, P., Kushwah, S. and Salo, J. (2020), "Why do people buy organic food? The moderating role of environmental concerns and trust", Journal of Retailing and Consumer Services, Elsevier, Vol. 57, 102247.

Verma, V.K. and Chandra, B. (2018), "Intention to implement green hotel practices: evidence from Indian hotel industry", International Journal of Management Practice, Inderscience Publishers (IEL), Vol. 11 No. 1, pp. 24-41.

Wang, J., Wang, S., Wang, Y., Li, J. and Zhao, D. (2018), "Extending the theory of planned behavior to understand consumers' intentions to visit green hotels in the Chinese context", International Journal of Contemporary Hospitality Management, Emerald Publishing, Vol. 30 No. 8, pp. 2810-2825.

Wu, L. and Chen, J.-L. (2005), "An extension of trust and TAM model with TPB in the initial adoption of online tax: an empirical study”, International Journal of Human-Computer Studies, Elsevier, Vol. 62 No. 6, pp. 784-808.

Yacoub, L. and ElHajjar, S. (2021), "How do hotels in developing countries manage the impact of COVID-19? The case of Lebanese hotels", International Journal of Contemporary Hospitality Management, Emerald Publishing, Vol. 33 No. 3, pp. 929-948.

Yadav, R., Balaji, M.S. and Jebarajakirthy, C. (2019), "How psychological and contextual factors contribute to travelers' propensity to choose green hotels?", International Journal of Hospitality Management, Elsevier, Vol. 77, January, pp. 385-395.

Yadegaridehkordi, E., Nilashi, M., Shuib, L., Nasir, M.H.N.B.M., Asadi, S., Samad, S. and Awang, N.F. (2020), "The impact of big data on firm performance in hotel industry", Electronic Commerce Research and Applications, Elsevier, Vol. 40, March-April, 100921.

Yu, Y., Li, X. and Jai, T.-M.C. (2017), "The impact of green experience on customer satisfaction: evidence from TripAdvisor", International Journal of Contemporary Hospitality Management, Emerald Publishing, Vol. 29 No. 5, pp. 1340-1361.

Zainal, N.T.A., Harun, A. and Lily, J. (2017), "Examining the mediating effect of attitude towards electronic words-of mouth (eWOM) on the relation between the trust in eWOM source and intention to follow eWOM among Malaysian travellers", Asia Pacific Management Review, Elsevier, Vol. 22, pp. 35-44.

\section{Corresponding author}

Dharmendra Kumar can be contacted at: zealaman@gmail.com

For instructions on how to order reprints of this article, please visit our website: www.emeraldgrouppublishing.com/licensing/reprints.htm Or contact us for further details: permissions@emeraldinsight.com 